\title{
Confined by Conflict, Run by Relief: Arabs, Jews, and the Finnish Mission in Jerusalem, 1940-1950
}

\author{
Seija Jalagin
}

In November 1947, the United Nations' decision to accept the partition of Palestine reached Jerusalem, where Finnish missionaries for the Jews also rejoiced, together with their local co-workers, children at the mission school and their Jewish neighbours. "The partition did not fulfil all hopes", wrote Aili Havas, the leader of the mission, in her annual report and later in her memoir that was published in 1958. She also described the antagonism that followed:

The Arabs declared a three-day strike, started to burn down Jewish shops and blow up Jewish houses in those parts of the town where Jewish and Arab shops stood next to one another. The Jews, who lived amidst Arabs, left their homes and moved to completely Jewish areas and the Arabs moved from the Jewish Quarter to the Old City. The partition was complete. $^{1}$

This article investigates the views of the Finnish missionaries towards the Arabs, and more broadly, the political and social circumstances in Palestine/ Israel. The Finnish mission focused solely on the Jews and was, like many other foreign religious actors, a marginal, grass-roots actor during the turbulent 1940s in the Middle East. Regardless of their size the different Christian denominations, missions and an increasing number of pilgrims were participants in the religious, social and political reconfiguring of Mandatory Palestine, where the British rulers struggled to balance the coexistence of the Arab population and the Yishuv, the Jewish settlement. What makes the Finnish mission particularly interesting is that the Finns, much like the other Nordic missions and missionaries, promoted an idea of the Nordic people as politically neutral in the Middle East and in other colonial settings. They claimed neutrality, as opposed to the

1 Aili Havas, Työkenttäni Israel (Helsinki: Suomen Lähetysseura, 1958), 229-23o. 
British and other missions and church bodies from European powers that had a presence in the Middle East due to Mandatory rule and other historical reasons. $^{2}$

The Nordic missions, in fact, had no political back-up-or oppositionfrom their home governments but it would be false to assume that the missionaries were politically neutral. As the case of the Finnish mission indicates, living amidst the political, religious, and social reality of Mandatory Palestine, and later in the State of Israel, drew partition lines not only through the local population but also through the foreign missionaries.

Of particular interest in this chapter is how the Finnish missionaries viewed the political and religious development in Palestine and how this linked to their own political views. The viewpoints of the missionaries were, of course, strongly affected by their religious ideology but it is equally important to explore how they related to their political standpoint. Going about their daily lives in Jerusalem and building a social reality in relation to local people, the missionaries became internal others, ${ }^{3}$ informed outsiders, who relayed knowledge about Palestine/Israel to their home countries and, at the same time, reflected on the local reality with their own national and cultural insights. They were regarded as either useful or harmful internal others by the ruling authorities - the administrators during the Ottoman era, British Mandate, or later the government of Israel - or they were simply tolerated. In much the same way, local people perhaps thought that the missionaries were either aligning themselves with the ruling authorities or distancing themselves from them. In order to analyse the missionaries' views, I rely on their correspondence with mission leaders in Finland as well as their published writings in mission and other religious papers, where they reported on the situation in Palestine/Israel and commented on its political, economic and social development.

2 For a broader view of the Christian presence in Palestine, see for example Anthony O'Mahony, ed., The Christian Communities of Jerusalem and the Holy Land (Cardiff: University of Wales Press, 2003).

3 "Internal Other" is a concept discussed by, e.g., Johnson and Coleman when addressing regional differences and nation-building. They define it "as the intentional construction of a region as different from, perhaps even antithetical to, national norms and values as an element of nation-building." For Johnson and Coleman, and to the geography researchers who have employed the concept, "internal other" centres on geographic and spatial entities, and not on individuals. Corey Johnson and Amanda Coleman, "The Internal Other: Exploring the Dialectical Relationship Between Regional Exclusion and the Construction of National Identity," Annals of The Association Of American Geographers 102, no. 4 (2012): 863-880, https:// doi:10.1080/00045608.2011.602934. 


\section{Lived Christianity among the Jews}

The Finnish mission to the Jews in Palestine was launched in the 1920 after decades of interest in Christianizing the Jews. Mission work among the Jews in Finland, who had mostly come from Russia and had no civil rights in the country before the independence (gained from Russian rule in 1917), had not borne much fruit. A few individual missionaries had been assigned to work among the Jews in continental Europe, but in general, the whole effort was small and unorganized until the oldest and largest mission organization in Finland, the Finnish Mission Society took it over. ${ }^{4}$ FMS was established in 1859; today it is known as the Finnish Evangelical Lutheran Mission (FELM). It is a mainstream Lutheran mission and a long-time co-operative organization with the Evangelical Lutheran Church of Finland, ${ }^{5}$ as well as the largest development co-operation body in Finland. It has historically operated in Southwest Africa (from 1870) and in China (from 1902), before expanding to other areas in Africa, Asia, and Latin America. ${ }^{6}$

FELM's mission work in Palestine started in 1924 when the Reverend Aapeli Saarisalo, later Professor of Oriental languages at the University of Helsinki, was sent there as a missionary. During his two years in the area, the mission made very little progress and in 1926 the Saarisalo family returned home. Saarisalo had prioritized scholarly work but also disseminated Bibles among the Jews and the Arabs that he encountered on his field trips in the

4 There was an increasing interest in the so-called Jewish question in Finland since the 187os. In FMS several leading characters were enthusiastic about mission work among the Jews. Some of them had in the 1880s tried to establish an independent mission association to proselytize the Jews, but the Czar of Russia had refused the application. Funds for mission work among Jews were collected in the parishes of the Evangelical Lutheran Church of Finland. An early example of more institutional work among the Jews is the school, or rather kindergarten, for Jewish children in Helsinki, in 1889-1891, and before that shortly in Turku and Helsinki around 1878-1881, with Finnish teachers. Toivo Saarilahti, Sata vuotta suomalaista lähetystyötä. 1, 3, Lähetystyön läpimurto: Suomen lähetysseuran toiminta kotimaassa 1895-1913 (Helsinki: Suomen Lähetysseura, 1989), 101-107; Per Wallendorff, Suomen lähetysseuran juutalaislähetystyön historia (Helsinki: Suomen Lähetysseura, 1958), 14-16.

5 The Evangelical Lutheran Church of Finland is a "folk" or "national" church, with less than $70 \%$ of the population as its members, and it has the right to collect taxes from these members via the state taxation system. The Orthodox Church of Finland, an autonomous church under the Ecumenical Patriarchate of Constantinople, has a similar status, with $1.1 \%$ of the population of Finland as its members.

6 The work in Israel continues today but has since the late 196os been directed first towards the Arabs, and later along more ecumenical lines among the diverse ethnic and religious groups in the area. 
region. ${ }^{7}$ It took until 1932 to send the next missionary to Palestine. Aili Havas (1903-1988), who held university degrees in both theology and history and had been internationally active in the Christian student movement, was commissioned by the FELM director to settle in Jerusalem as a missionary to the Jews with no specific instructions other than "let God show you the way from the very beginning. We do not wish to take our civilization there, they do not need it, nor do we want to take our own Lutheran Church there but only Christ". ${ }^{8}$

During the next 37 years in Palestine/Israel, Havas became the undisputed leader of the Finnish mission to the Jews there. She had an academic orientation and was, in general, a steady person, who succeeded in running and navigating the mission in the politically turbulent, multi-ethnic, and culturally diverse surroundings. On the other hand, it could also be said that her success resulted from her finding a niche for the FELM's mission work among the Jews. This becomes vividly clear when investigating the Finnish mission during the World War II years and the restless times at the end of the British Mandate and the evolution of the State of Israel. When most British missionaries left Palestine at the end of the Mandate in 1947 and some Nordic missions gave up their work among the Arabs, the Finnish missionaries found opportunities among the Jews. This, however, required careful balancing between Jewish nation-building and religious diversity.

After her arrival in Palestine as a young academic, Havas had enrolled at the Hebrew University in Jerusalem. Soon she also aimed at getting a $\mathrm{PhD}$ degree there. Her missionary strategy was based on living among the Jews as an openly Christian person, and she used every opportunity to make friends with her fellow students. Gradually this developed into a plan to open a student home where she could gather young Jews to study the Bible and discuss religious issues. Soon after getting the student home started Havas had to leave Jerusalem in 1938 to go on furlough in Finland for rest and recovery from pulmonary tuberculosis.

When she returned in 1940, the mission home she had left under the care of a Swiss-Jewish female friend was full of refugees from Europe. The mission house had turned into a "Samaritan inn", ${ }^{9}$ as one of the young men residing there called the home that also gave shelter to a mother with a young daughter as well two young orphaned children. Havas prioritized to care for the children

7 André Swanström, From Failed Mission to Apocalyptic Admiration: Perspectives on Finnish Christian Zionism (Åbo: Åbo Akademi, 2007), 8o-82.

8 Havas, Työkenttäni Israel, 29-30.

9 Aili Havas to Rauha Moisio, Jerusalem (May 21, 1940). Folder 15, Aili Havas Collection, FMS Archives (FMSA), Finnish National Archives (FNA), Helsinki. 
and "our small family", as she called their community, became the nucleus of a future children's home, with Mrs Margot Moses as Mutti, "the mother" and Aili Havas as "the father", as she referred to herself. The political and military atrocities in Europe had thus permanently changed the Finnish mission's agenda in Palestine.

Ever since Havas had participated in the international conference of the mission to the Jews in Vienna in 1937, she had been painfully aware of the situation of European Jews. During World War II, she focused increasingly on humanitarian efforts among the Jewish refugees in Palestine, to which the mission home with orphaned children gave an impetus. In the post-war years it was only natural to continue relief work when Jewish migration to Palestine continued and intensified after Israeli independence. In 1946 Havas came into contact with a Jewish refugee woman who had converted to Roman Catholicism and who told Havas about her young nephew's fate. The boy's parents (also converted Jews) had died and the aunt wished to bring the boy to Palestine. "The boy is just the kind of child I hope I could help. Pray for little Peter", Havas wrote in her letter..$^{10}$ In the same manner she gave a vivid description of the need for humanitarian work among the Jewish refugees, the children in particular. Rafael, one of the first children in the Finnish mission's small home school run by Havas, was "a malnourished, nice boy" and his father, a converted Jew, paid for his son's upkeep, even though he was "poor and ailing". 11 The following year, Rafael's younger siblings, Lea and Ora, came to the mission home. "For the youngest we arranged a place in an orphanage in Beth-Jala. At the very first instance, I took scissors and cut Ora's [2.5 years] and Lea's [ 5 years] hair for they were full of vermin. In a few days they were like new: did not act up but ate peacefully and obeyed." Both children were underdeveloped, including in terms of speech development, and Ora had suffered from polio, Lea from dysentery. "Pray for these poor little ones. Their parents are converted Jews but the mother is unable to care for them. Poverty is devastating", wrote Havas to her circle of mission friends and supporters in Finland. ${ }^{12}$

10 Aili Havas to Rauha Moisio [no date] (1946). Folder 15, Aili Havas Collection, FMSA, FNA, Helsinki.

11 Havas also reported that the parents paid for their children's upkeep, but in case of sickness and unemployment the payments were not required. Aili Havas to Mission director Tuure Vapaavuori, Jerusalem (November 3, 1945). Folder 15, Aili Havas Collection, FMSA, FNA, Helsinki.

12 Rauha Moisio cites Aili Havas' circular letter [probably in spring 1946]. Rauha Moisio to mission friends, Helsinki [no date] (1946). Folder 15, Aili Havas Collection, FMSA, FNA, Helsinki. 
Humanitarian work did not stop Havas from working among the adult Jews and among those who had converted to Christianity. She was invited to act as the chairperson of the Jerusalem section of the Hebrew Christian Alliance, the association of converted Jews. As a goy, a foreigner, she was apparently trusted as a neutral figure in this group of Jews who had converted to Christianity and were somewhat conflicted within themselves. In a vulnerable position herself, coming from Finland, an enemy of the Allied powers and at war with the Soviet Union, ${ }^{13}$ British Mandate officials placed Havas under surveillance, her correspondence was censored ${ }^{14}$ and transfer of funds from Finland cut off. ${ }^{15}$

In order to develop the mission work and the Christian presence in Palestine Havas came up with an ambitious plan in 1943-1944: The Nordic missions could join forces and establish a Christian Hebrew Centre in Jerusalem. ${ }^{16}$ It would have included several homes for Jewish refugee children with missionary women as their "mothers", a Christian school with Hebrew as the main language of education and a scientific centre for the study of Judaism, along the model of the Delitzschianum in Leipzig where Havas had visited on her way to Palestine in 1931. She worked hard to realize the plan and to convince the Swedish missions in Palestine and their respective organizations at home about the project. Some of the Scottish and English missionaries supported the idea, and the Swedish Israel mission's director even visited Helsinki to discuss the plan with the FELM leaders. To Havas' disappointment, nothing came out of the co-operation. Instead, she began a home school for the children at the mission home and later a kindergarten when her first Finnish co-worker, Rauha Moisio, finally reached Jerusalem in $1946 .{ }^{17}$

Even though the Finnish missionaries focused on Jews - which is very explicit in their published writings - they were familiar with other missions and

13 Finland fought against the Soviet Union first in the Winter War, 1939-1940, and again from 1941 to 1944 as an ally of Germany. See e.g. Tiina Kinnunen and Ville Kivimäki, eds., Finland in World War II: History, Memory, Interpretations (Leiden: Brill, 2011).

14 Since Havas was the only Finnish-speaking individual in Palestine, she was called to inspect her own correspondence. Soon the mandate officials realized that censorship was useless in Havas' case. The letters did not, however, travel well between Finland and Palestine, and Havas had to write to FELM via Swedish mission organizations.

15 Seija Jalagin, "Transnationalising Education for the Benefit of the Nation: Finnish Mission to the Jews in post-World War II Jerusalem," in Transnational and Historical Perspectives on Global Health, Welfare and Humanitarianism, eds. Ellen Fleischmann, Sonya Grypma, Michael Marten, and Inger Marie Okkenhaug (Kristiansand: Portal Forlag, 2013), 182-2O7.

16 For a more detailed analysis on the plan, see Seija Jalagin, "A Nordic Hebrew Christian Centre in Jerusalem?" Scandinavian Journal of History 40, no. 3 (2015): 455-477, https://doi .org/10.108o/03468755.2015.1039058.

17 Jalagin, "Nordic." 
individual missionaries in Palestine, including those who worked among the Arabs, or among both the Arabs and the Jews. For example, Miss Lawrence and Miss Hannah Hurnard, who toured Palestine with Hurnard's car and tried to visit all the Jewish colonies and Arab villages, are among the missionary friends that Havas describes in her memoir. So is the Danish-Norwegian couple, Eli and Karen Bøgh, ${ }^{18}$ who had come to Palestine in 1938 from Denmark as independent missionaries. With the Bøgh couple, Havas shared similar ideas about living as exemplary Christians among the Jews. And as Michael Marten writes in his article in this volume, this became a typical strategy for many Western church traditions in Palestine where "attempts to generate conversions were remarkably unsuccessful"..$^{19}$ Inger Marie Okkenhaug has also pointed to this strategy, "the embassy role" by some British missionary schools, such as the Anglican Church affiliated St Mary's Home and school for Jewish girls in Jerusalem. Contrary to the mission schools of British origin that relied on English as the uniting linguistic medium, particularly in multinational schools that took Jewish, Muslim and Christian students, ${ }^{20}$ Havas and the Bøghs nurtured the Hebrew language as the uniting force for the diverse groups of Jews that were migrating to Palestine. ${ }^{21}$ Another independent missionary, the Finnish Elna Stenius, who lived on meagre support from a British mission, settled in the Finnish mission house in the wwII years. Havas writes how Stenius strolled in the streets of Jerusalem to disseminate religious leaflets

rain or shine and discussed with people. Sometimes a bunch of boys, who shouted and mocked her and would not leave her alone [...]. Such street proselytizing was heavily criticized by other missionaries. They did not think it was suitable for the value of the gospel, particularly when Elna sometimes threw her leaflets in the middle of the people or forced them to listen to what she had to say. [...] Extremely competent in lan-

18 Havas, Työkenttäni Israel, 218-220.

19 Marten in this volume.

20 Inger Marie Okkenhaug, "Education, Culture and Civilization: Anglican Missionary Women in Palestine," in The Christian Communities of Jerusalem and the Holy Land, ed. Anthony O'Mahony (Cardiff: University of Wales Press, 2003), 175-181, 192-196.

21 Eli and Karen Bøgh had met when they had both worked in India as missionaries. Karen (1904-1989) was born in Bergen, Norway and trained as a nurse and a teacher, whereas Eli (1893-1981) was a civil engineer. They married in 1932 and returned to Denmark. Their work in Palestine and Israel in 1938-1972, is described in more detail by Bodil F. Skjøtt, "Eli and Karen Bøgh-Bible Missionaries in Israel," Mishkan: A Forum on the Gospel and the Jewish People 41 (2004):38-48, http://www.caspari.com/wp-content/uploads/2016/o6/ mishkan41.pdf. 
guages, she could converse with anyone. Besides Finnish and Swedish, she spoke fluent English, French, Italian, Spanish, Arabic, even quite good German and satisfactory Hebrew. For myself, Elna Stenius has been a vivid sermon of loyalty and endurance and self-sacrificing love in God's work. $^{22}$

An important missionary figure and a powerful example to Aili Havas was the Swedish missionary, Signe Ekblad, the director of the Swedish School for Arab children in Jerusalem from 1922 to 1948 . The school was run by the Swedish Jerusalem Society, a High Church organization with powerful supporters in Sweden. Ekblad was in close contact with the British Mandate authorities, and similar to many British missionaries, pro-Arab. ${ }^{23}$ After all, the Arabs were the allies of the mandate rulers, while the British tried to maintain the ethnic and political status quo in Palestine. Following the Arab protests of 1936-1939 against Jewish immigration and land acquisitions in Palestine, the British government issued a white paper in 1939 that restricted Jewish immigration to 75 ,0oo for the coming five years. ${ }^{24}$

On her return to Palestine in 1940, Havas observed the change in atmosphere. While on holiday in the vicinity of Bethlehem she

noticed the change in the Arab population. They now seemed happy and free, the sullen face of the restless time [in 1936-1937] was gone. After all, England had promised them what they wanted. The Jews are also quiet, even though the white paper crushed their national aspirations. They know that only the victory of England can save them from Hitler. It is difficult to say how reliable the "friendship" of the Arabs will be. ${ }^{25}$

At the monthly receptions at the Swedish School, Ekblad intended for the invited people from "different circles, denominations, and nationalities to exchange ideas and acquaint themselves with one another in amity". On these occasions "one could meet a Jewish academic or medical doctor, Arabic teach-

22 Havas, Työkenttäni Israel, 206-208.

23 Inger Marie Okkenhaug, "Children, Women and Welfare in Jerusalem: A Swede in Jerusalem; Signe Ekblad and the Swedish School 1922-1948," in En svenska i Jerusalem: Signe Ekblad och den svenska skolan 1922-1948 (Betlehem: Diyar Publishing; Svenska Jerusalemsföreningen/Swedish Jerusalem Society, 2012).

24 Colin Shindler, A History of Modern Israel, 4th printing (Cambridge: Cambridge University Press, 2011), 37.

25 Aili Havas' circular letter, Bet-Jala [Beth Jala or Beit Jala] (August 20, 1940). Folder 15, Aili Havas Collection, FMSA, FNA. 
ers and administrators, representatives of the English Mandate, missionaries from different denominations, German deaconesses, and Jewish social workers", wrote Aili Havas in her memoir. ${ }^{26}$ Despite such influences, Havas was more inclined to associate with the Jews. She was carving out her "own Jerusalem", much like the leader of the American Colony, Bertha Spafford Vester, was doing, as Heleen Murre-van den Berg writes about Vester's inclination to distance herself from the Palestinian Christians among the different Christian communities in Mandatory Palestine. ${ }^{27}$ For the Finnish mission, Signe Ekblad eventually became a missionary friend in need. She helped Havas when the British authorities intended to arrest her during WwII. In 1948, when Ekblad was forced to close the Swedish School and leave Israel, she gave the rest of the food supplies to the Finnish mission so that the children and adults could survive the violence and siege during the war between Israel and the Arab states. ${ }^{28}$

When the War of Independence (as Israel calls it) or the Nakba ("the catastrophe", as the Arabs call it) ended in 1949, Havas, Moisio and their local coworkers settled in Israel to stabilize their work in Jerusalem. By 1958, the institution hosted a home for almost 5 o children between the ages 3 and 15 , and the premises consisted of several buildings to accommodate children and adults, kindergarten and school under the name Shalhevetyah, "Flame of God". ${ }^{29}$ As the work expanded, it gained a foothold, even though the Israeli authorities never gave official accreditation to the school. The graduates, however, passed the government-regulated curriculum (with additional Christian classes) and could pursue higher education. The Finnish missionaries put their energy wholeheartedly into bringing up the Jewish children as Christians. They also supported the construction of the Jewish state of Israel.

In 1947, in the FELM Christmas magazine Tulkoon valtakuntasi ("Thy kingdom come") Havas reflected on the influence of the Jews in Palestine as well as the change in their mentality. While the newspapers in the Western world reported on violent attacks, bombs, and explosions, the Hebrew newspapers

\footnotetext{
26 Havas, Työkenttäni Israel, 128.

27 Heleen Murre-van den Berg, “'Our Jerusalem': Bertha Spafford Vester and Christianity in Palestine during the British Mandate," in Britain, Palestine and Empire: The Mandate Years, ed. Rory Miller (Farnham, Surrey: Routledge, 2010).

28 Havas, Työkenttäni Israel.

29 Havas, Työkenttäni Israel, 274.
} 
in "Eretz Israel (= Palestine)" wrote about new agricultural colonies, the transformation of malaria-contaminated wetland into fertile fields. Described by Havas, the economic activities of the Jews seem superb. She also uses the phrase "Eretz Israel", the "land of Israel", as was common to those whose aim was to portray the region as the biblical promised homeland of the chosen people, identical to the Jewish nation-state of Israel. According to Israeli historian Shlomo Sand, this resulted in eliminating Palestine as the name of the geographical region and as the home of Arabs in the area. ${ }^{30}$

While rejoicing in the success of the Jews in building their own nation-state, Havas also expressed deep concern of violent nationalism:

In the early 1930s the Zionist young people still said that Zionism is a peaceful movement that with its moral force and energy will conquer the land, and that a Jew could never kill another human being.- - The present young generation says: The moral level of Europe is so low that only bloodshed and fear of a new war can affect it. We must show that we can also fight with a gun in our hand, that we can be dangerous!

According to Havas, the armed underground organizations were extremely dangerous to the morals and inner life of the people because they threatened "to ruin all that the people of Israel had built in Palestine through great sacrifice". ${ }^{31}$ Similar to Havas, teachers in the British mission schools regarded nationalism as a threat to the stability of Mandatory Palestine society. Maria Småberg has shown that the teachers spoke of it as false nationalism that threatened both the missions' "spiritual solution" as well as their promotion of unity in Palestine. ${ }^{32}$ In general, whilst admiring, as Marten states in this volume, "the Zionist colonizers in modernizing agriculture and economy [...] the missionaries would have preferred the local Palestinian population to have adopted their version of European modernity".33

Havas, for her part, writing after the mandate era, during the first years of the State of Israel, was very pro-Jewish nation. She expresses nothing of the

$30 \quad$ For an analysis of the significance of naming the area, see Shlomo Sand, The Invention of the Land of Israel: From Holy Land to Homeland, transl. Geremy Forman (London: Verso, 2013).

31 Aili Havas, "Nähtyä ja elettyä Raamatun maasta," Tulkoon valtakuntasi. Suomen Lähetysseuran joululehti (1947) [Thy kingdom come. Christmas magazine of FE LM (1947)].

32 Maria Småberg, Ambivalent Friendship: Anglican Conflict Handling and Education for Peace in Jerusalem 1920-1948 (Lund: Lund University, 2005), 390-391.

33 Marten in this volume. 
idea of unity between different national and religious groups that the British missionaries had considered central just a few years earlier.

In 1949, in the first issue of Karmel, a magazine published by the Finnish Karmel association that had Christian Zionist ideas about the Israeli State and Jews as the chosen people of God, Havas focused on the right of the Jews to live in Palestine together with the Arabs, and on patriotism and nationalism as potentially destructive ideologies that alienated people from God. When considering the demands of both the Arabs and the Jews in Palestine, Havas positioned herself as someone from another small nation "that had almost from generation to generation had to fight for its life and existence" and she could thus relate to "the fate and problems of other small nations, which I can see from inside." She could feel in her heart what "an educated Arab felt when seeing foreign people settle in the mountains and valleys that his own people had considered their own for centuries." However, Havas herself could relate even more to "the people of Judea who had for centuries and millennia kept in their heart the vision of returning to the promised land, of uniting the people in the diaspora and elevating it to its former place". ${ }^{34}$

According to Havas, both the "colourful population of Palestine" as well as the Jews, "whose mental bond to the Holy Land had never broken" and who "had no other place in this evil world" had the right to inhabit Palestine. There was so much land that had the Jews not settled there, some other people would have, and, according to Havas, Arabs, and Jews could have more amiable relations than Arabs and any European people, for example. Nonetheless, overt nationalist feelings should be kept in control, even though "love for one's people and fatherland" was required in order for people to be able to love other peoples. "Natural feeling of nationalism and patriotism include a lot of selfishness and pride" that had caused wars and oppression of the weak. To fight that, Havas, who confessed to having herself earlier made God the humble servant of Finnish nationalism, propagated the idea that Christians should regard themselves as strangers on earth. This did not refer to cosmopolitanism, however, which for Havas was only the highest form of selfishness and a mask for moral decline. $^{35}$

For Havas Jews came first, but she was optimistic that there was room for Arabs as well in Palestine. She was sympathetic to the Arabs, even those who took up arms when they realized that the Jews had come to Palestine to build a national homeland there instead of "living as guests like among other

34 Aili Havas, "Kansa ja Usko," Karmel, näytenumero (1949) [Karmel, first issue (1949)].

35 Aili Havas, "Kansa ja Usko," Karmel, näytenumero (1949). 
peoples". ${ }^{36}$ She felt that "the Jews had a higher cause on their side" even though she "had often asked herself which of the two to stand for". The "so-called Palestinian Arabs were a mixed people who spoke Arabic" and who had also "Jewish and crusader and other conqueror blood in them". In addition, the land inhabited by the Arabic speaking peoples was "incredibly wide and sparsely populated". Jerusalem was religiously sacred for the Muslims, too, but Havas regarded this a result of a false legend of Mohammed's steed. The real religious centre of the Muslims, according to Havas, was Mecca, not Jerusalem. ${ }^{37}$

"Whereas the Arabs had Syria, Lebanon, Iraq, Jordan, Arabia, and Egyptfor the Jews Israel was the only land where they could be masters in their own house, and even this land was sadly reduced." For the Jews it was " 'een bereraa', there is no other choice, there is no other place they could go". Jordan and Syria could instead welcome the Palestinian Arab refugees. Polemically she continued: "Must the national aspirations of the Arabs be filled 100\% but those of the Jews not at all!"38

Havas argued for the right of the Jews to build their national homeland in Palestine/Israel with the historical bond between the Jews and the Holy Land, as narrated in the Old Testament and reinforced by Jewish cultural traditions. ${ }^{39}$ She also praised the Jews for their vigour in developing Palestine economically, unlike the Arabs who lived in poverty or at least were not cultivating the land or advancing industry. ${ }^{40}$

As James Renton has pointed out, the British Middle East specialist in the early 2oth century did not consider the Arab population a single community but rather "viewed [them] in racial terms as a mixed, and therefore degenerate, bunch of peoples". The Balfour declaration of 1917 echoes this in its phrase of "non-Jewish communities in Palestine" which made the Arab question a minority issue while the British Mandate rulers treated the Jews as a national community, ${ }^{41}$ much the same way that Havas reasoned in 1949.

${ }_{36}$ Aili Havas, "Ajatuksia ja kokemuksia 20 vuoden varrelta Israelin keskuudessa," Suomen Lähetyssanomia 2 (1953).

37 Ibid.

38 Aili Havas, "Israel ja arabit," Suomen Lähetyssanomia 3 (1953).

39 Aili Havas, "Juutalaiset ja Erez Israel," Suomen Lähetyssanomia 6 (1953).

40 Ibid.

41 James Renton, "Flawed Foundations: The Balfour Declaration and the Palestine Mandate," in Britain, Palestine and Empire: The Mandate Years, ed. Rory Miller (Farnham, Surrey: Routledge, 2010), 22-23, 37; and also Motti Golani, "Palestine, 1945-1948: A View from the High Commissioner's Office" in the same volume, 182. 
The missionaries in Israel faced the evolving Jewish nationalism in the building of a Jewish state as well as their own otherness as Christian Europeans who were responsible for the Holocaust, the killing of 6 million Jews in the Nazi concentration camps.

In 1951, Rauha Moisio titled her article in the FELM magazine, Suomen Lähetyssanomia, "The debt of Christians to Israel" to discuss the responsibility of Finns as a Christian people and as individuals to "the heathens and the Israelis". The aim was, as has been typical for mission publicity efforts, to solicit spiritual and financial support for the mission, but also to illuminate the circumstances in Israel. The missions and missionaries as well as the Christian Jews in Israel had been criticized for not "participating in the war of independence". According to Moisio, many missions withdrew from Israel when the British Mandate ended in May 1948, but some stayed and gave shelter to the homeless, and provided medical care and spiritual support. The Finnish mission took care of 15 Jewish children and some families who had lost their homes in bombings. In addition to the sense of shared guilt for the Holocaust, the missionaries faced accusations of not supporting the fight for freedom of the Jews in Palestine. For Moisio, the independence of Israel, "the constant flow of the Israelis by ships and planes to their own land [...] 8 oo to 1,500 per day in 1949", was, by Christian Zionist ideals, proof of how "the Lord has now clearly shown that He is moving forward. The State of Israel is a fact".42 Havas recognized the challenge that the diverse Jewish groups posed to the unity of the nation and therefore supported wholeheartedly the emphasis on Hebrew as the unifying force. ${ }^{43}$ That is why the Shalhevetyah Christian School for Jewish children used Hebrew as its primary language, and that is how it also actively participated in the construction of the Jewish nation and state in Israel. As the population of Israel in the early 1950s doubled with the flow of Jewish immigrants from the

42 Rauha Moisio, “Kristittyjen velka Israelille," Suomen Lähetyssanomia 2 (1951).

43 The revival of Hebrew, the ancient religious language of Judaism, was one of the major victories of Zionism, but it was a long process in Palestine. At the end of the 19th century, French was the language of instruction in many schools. Some proponents campaigned for Hebrew to become the primary language of education and for Jews to replace their diaspora names with Hebrew names, which Beilin calls the "stubborn war for the Hebrew language" and a way of beginning a new life in Palestine and a separation from one's past life in the diaspora. This echoed the understanding of history that aimed to reintegrate Jews in Palestine with ancient history and erase the intervening centuries. Yossi Beilin, Israel: A Concise Political History (New York: St Martin's Press, 1992), 132135 . 
Middle East, Africa, and Europe, the Israeli government aspired to indoctrinate and assimilate the new-comers, through education and military service, in particular. ${ }^{44}$

The article by Moisio also indicates the difficulties of the Christian missionary agenda, even though their civilizing mission to educate the Jewish children with Hebrew as the main language (albeit with the Christian faith also included in the curriculum) seems to have been in line with the Jewish nation-building efforts. On one hand, they relied on their strategy to live as exemplary Christians and on the other hand, they needed to respect the authority of the Israeli government. Spiritually this was not difficult, because they could regard the Israeli state as the embodiment of God's plan for his own people, as Rauha Moisio wrote, and, as Aili Havas had noted, it reminded them of the Finnish people's fight for their freedom from Russian rule and towards an independent state in 1917. Even the Finnish Civil War in 1918 resonated with the experiences of the two missionaries in Israel in $1948-1949 .{ }^{45}$

Conversely, it meant that the Arabs were the invisible others to the Finnish missionaries. In fact, not much attention was paid to the Arabs because the Jews, with their history and fate in the Holocaust, came first. Moisio illustrated this vividly:

Indeed, we feel helpless and lack strength in all possible ways in front of this great task. In Israel, it is not possible to meet a European Jew who has not lost a relative in concentrations camps. It was agonising to watch the funeral convoy in the streets of Jerusalem where the ashes of 30 nameless victims of concentration camps had been flown from Austria to Tel Aviv and further taken by hearse to the soil of their fatherland. ${ }^{46}$

The missionary texts in the FELM magazine no doubt give a somewhat biased view of the missionaries' reality in Israel. They mostly wrote about the Jews because they worked to missionize them, and the supporters at home par-

44 Ari Ariel, "Ethnic Diversity in Israel," in The Wiley-Blackwell History ofJews and Judaism, ed. Alan T. Levenson (Oxford: Blackwell, 2012), 587-588, https://doi.org/10.1002/9781118232897 .ch34.

45 Seija Jalagin, "Vieraalla maalla kaukana: Aili Havaksen transnationaali elämä," in Historiallinen elämä: Biografia ja historiantutkimus, eds. Heini Hakosalo, Seija Jalagin, Marianne Junila, and Heidi Kurvinen (Helsinki: sKs, 2014). 
ticularly wanted to donate to evangelizing the Jews regardless of its meagre success. ${ }^{47}$ In fact, the missionary presence in Israel, or more likely in the imagined "Land of Israel", was more important than the actual number of conversions.

In an article in 1950, Havas described the hardships of the previous year and the struggles of the Israeli government to overcome them. Peace treaties with neighbouring Arab countries had been settled but the future of divided Jerusalem remained unresolved. Unemployment, housing problems, a shortage of teachers and nurses, and health issues were the biggest concerns after the rapid rise in population due to immigration. The will to defend the country was strong and Havas continued that

should the Arabs start to cause trouble, the Israelis could at any time occupy all of Jerusalem, not to mention the whole of Palestine on the west bank of Jordan. But the people wish to remain in peace.

Spiritual awakening was non-existent, as was religious freedom in the Finnish sense, even though the missionaries could operate freely. Among those converted Jews who were openly Christian, Havas witnessed separatist activity: "they want to break free of all organized church bodies and missions, which they openly criticize and consider foreign elements". According to Havas, the social position of the converted Jews was very difficult. Finding employment was extremely hard. ${ }^{48}$ The construction of the Jewish national project that the Finnish missionaries admired and that they paralleled with the building of their own country in the 1920s was a double-edged sword, as it alienated converted Jews from the international Christian communities. ${ }^{49}$

The published texts and correspondence of the Finnish missionaries in Palestine/Israel in the 1940s and early 1950s demonstrates how pro-Jewish and pro-

47 During the first ten years of the independent Israeli state, only two people had been baptized by the Finnish missionaries. Swanström, From Failed Mission to Apocalyptic Admiration, 87 .

48 Aili Havas, "Miekalla ja muurilastalla," Suomen Lähetyssanomia 4 (1950).

49 The Bøghs also paid attention to similar tendencies, while understanding the young Christian Jews' need for independence. Skjøtt, "Eli and Karen Bøgh," 47. 
Israel they were. Observing the political and social development in the region, they advocated an idea (and interpretation of history) that Palestine formed the historical "homeland" of the Jews, who had maintained a bond with the Holy Land since the times of the Old Testament. The end of the Jewish diaspora would thus indicate the second coming of Christ on earth and fulfil the hopes of ardent Christians. Not even the destruction of 6 million Jews in the Holocaust made these Christians cease proselytizing the Jews and reconsider the supremacy of their Christian message. On the contrary, Aili Havas maintained that it was possible to be both an ethnic Jew and a devoted Christian, and to adhere to Jewish cultural traditions as well as the Christian faith and its rituals. Likewise, the missionaries' understanding of history was theologically grounded, which left the question of the Arabs' rights to live in Palestine open to other historical and political interpretations.

Aili Havas considered the right of the Arab population to live in Palestine from both religious and ethnic viewpoints. Religiously Jerusalem was the most critical point of conflict, but Arabs should instead give way to the Jews, since Mecca was the centre of the Muslim faith. Ethnically Havas undermined the Arabs by portraying them as a mixed people (yet offered no explanation to this view), whereas the Jews, despite their diverse backgrounds and cultural mixture from African, Middle Eastern, and European countries, were God's chosen people, who could unite with one language, Hebrew, and a strong state that oversaw the building of the Jewish national home. Havas and Moisio admired the Jews beyond all others because of their technological prowess and moral stamina in transforming Palestine into an economic success story and fighting for their independence against the Arab states, and finally also working to solve the problems caused by mass immigration. According to their argumentation, this reduced the majority of the Palestinian Arabs, living in refugee camps from 1948 onwards, into a practical problem that the neighbouring Arab states could solve, should they choose to take on the responsibility.

It is possible to explain the Finnish missionaries' religiously motivated political ideology with their nationalistic understanding - and indeed, experiences-of the developments in Finland since 1917. First, Finland had been under the rule of the Kingdom of Sweden for almost 700 years, from the mid12th century to 1809, and thereafter under the rule of the Czar of Russia as an autonomous grand duchy. Following the late 19th-century "national romantic" construction of Finland, the national narrative contained an idea of a homogenous people with ethnic, linguistic, and religious unity. But it also contained violence. The Finns paid a price for their independence, first in the Civil War of 1918 and then in the Winter War of 1939-1940 and Continuation War of 1941- 
1944 against the Soviet Union. ${ }^{50}$ Almost 100,ooo lives (2.6\% of the population) and $10 \%$ of Finnish territory were sacrificed for the nation's continued existence.

Even though Havas warned about overt nationalism, she had internalised the nation-state ideology that highlighted the right of every nation to a state of its own. On the other hand, the nation-state ideal also stood in contrast to the transnationality in missionary lives that, in general, consisted of crossing national, cultural, and state borders, settling in a foreign country as immigrants and using many different languages in diverse social and ethnic settings. Nonetheless, the national and the transnational seemed to find their place in one person and in a single missionary context. This demonstrates the adaptability and transferability of patriotism (if not nationalism) and the nation-state ideology.

It is more difficult to explain how the Finnish missionaries could close their eyes to the fate of the Arab refugees, particularly when their own work was based on humanitarian ideals. The Finnish missionaries moved from relief work to social and educational work in order to aid the Jewish holocaust refugees and vulnerable immigrant families in Jerusalem. They were also familiar with the humanitarian efforts of, for example, the Swedish missionary, Signe Ekblad, who organized food kitchens for the poor Arab families in the old city of Jerusalem in the $1930{ }^{5 .}{ }^{51} \mathrm{In}$ fact, in the preface to her autobiographical book of the mission in Palestine/Israel in 1958, Aili Havas wrote that "someone who had lived among the Arabs would maybe see many things differently" compared to herself, who had "lived among the Jews for 26 years". 52 This reads as only a modest note in a book that Havas had been commissioned to write in order to celebrate the 1ooth anniversary of FELM and describe the Finnish mission to the Jews in Palestine/Israel. On the other hand, her words also read as if someone living in Palestine/Israel was compelled to take sides. Although the private and published texts by Aili Havas give an insightful and enlightened view of the changing political, social, and religious circumstances in the region, they also suggest spiritual hopefulness, if not even strong belief, in the "homeland" of the Jews, "Eretz Israel", as a sign of Christ's Second Coming, much like the Christian Zionists articulated.

50 Interestingly, Finnish World War II history contains three wars with specific names. In addition to the Winter War and Continuation War against the Soviet Union, there is the Lapland War against the German troops in Finland, Finland's former allies, from October 1944 to April 1945 .

$5^{1} \quad$ Okkenhaug, "Children," 95.

$5^{2}$ Havas, Työkenttäni Israel, 6. 
Nonetheless, there remains an uneasy feeling about the depth of analysis at this level. Does religious conviction mean that an individual is likely to close her/his eyes to the prevailing social reality? In the case of Aili Havas, and possibly the other Finnish missionaries as well, this seems questionable. As we have seen, Havas reasoned that the Palestinian Arabs could find a home in the surrounding Arab countries, whereas living side by side with Jews was clearly not an option. The Jews deserved a state of their own and ethnic diversity was not an ideal solution. The nation-state ideal with one nation and preferably one language - be it Finnish in Finland or Hebrew in Israelwas the internalized order of nation-states for Havas. Population exchanges were also employed to solve ethno-political dilemmas, particularly in evolving states. They had already been tested in resolving the legacy of the Ottoman Empire, notably with Turkey and Greece exchanging 1.6 million people altogether. This model was later adapted in the partition of British India in 1947 into the independent states of India and Pakistan. Havas could also relate to the contemporary history of Finland for examples of population transfers in the name of a greater cause or necessity. At the end of the Civil War in 1918, some 10,00o Reds (left-wing fighters and their families) fled or moved to Soviet Russia, in fear of being imprisoned or executed, and conversely, more than 11,000 East Karelians from Russia fled to Finland after an unsuccessful revolt against Bolshevik rule in 1921-1922. During World War II, the Finnish government ordered more than 430 ,ooo Finns, $10 \%$ of the entire population, to move from their homes in Karelia, Salla, Kuusamo, and Petsamo, which were ceded to the Soviet Union according to the Moscow Armistice of September 1944 (which eventually also led to the Lapland War against the former allies of Finland, the German troops that had to be expelled from Finland). ${ }^{53}$ Thus, even though Havas had by 1958, and the publication of her account of the Finnish mission in Palestine/Israel, lived in Jerusalem for almost 30 years, the formative ideas of Havas and the other Finnish missionaries derived from the national historical narrative they had adopted as citizens of the emerging Finnish nationstate.

The pro-Jewish agenda of the Finnish missionaries eventually ended in the late 196os at the eve of Aili Havas' retirement. After the Six-Day War of 1967, the Finnish missionaries were more inclined to see things from the Arab point of view. At this point, enrolling Jewish children into Christian boarding schools became impossible because of new legislation. The Shalhevetyah School was 
forced to find new students. ${ }^{54}$ Soon it was full of Arab Christian children, which completely changed the agenda of the Finnish mission. ${ }^{55}$

\section{Bibliography}

Aili Havas Collection, FMS Archives (FMSA). Finnish National Archives (FNA), Helsinki.

Ariel, Ari. "Ethnic Diversity in Israel." In The Wiley-Blackwell History ofJews andJudaism, edited by Alan T. Levenson. Oxford: Blackwell, 2012.

Golani, Motti. "Palestine, 1945-1948: A View from the High Commissioner's Office." In Britain, Palestine and Empire: The Mandate Years, edited by Rory Miller, 177-187. Farnham, Surrey: Routledge, 2010.

Havas, Aili. Työkenttäni Israel. Helsinki: Suomen Lähetysseura, 1958.

Jalagin, Seija. "Transnationalising Education for the Benefit of the Nation: Finnish Mission to the Jews in post-World War II Jerusalem." In Transnational and Historical Perspectives on Global Health, Welfare and Humanitarianism, edited by Ellen Fleischmann, Sonya Grypma, Michael Marten, and Inger Marie Okkenhaug, 182207. Kristiansand: Portal Forlag, 2013.

Jalagin, Seija. "Vieraalla maalla kaukana: Aili Havaksen transnationaali elämä.” In Historiallinen elämä: Biografia ja historiantutkimus, edited by Heini Hakosalo, Seija Jalagin, Marianne Junila, and Heidi Kurvinen, 113-131. Historiallinen arkisto 141. Helsinki: SKS, 2014.

Jalagin, Seija. "A Nordic Hebrew Christian Centre in Jerusalem? Relief work, Education and Nordic Neutrality in Palestine, 1943-1946." In "Mission, Relief and Development: Gender and Nordic Missions in Transnational and Humanitarian Settings, ca. 189o196o," edited by Seija Jalagin, Inger Marie Okkenhaug, and Maria Småberg. Special Issue, Scandinavian Journal of History 40, no. 3 (2015): 455-477. https://doi.org/10 .1080/03468755.2015.1039058.

Johnson, Corey, and Amanda Coleman. "The Internal Other: Exploring the Dialectical Relationship Between Regional Exclusion and the Construction of National Identity." Annals of The Association of American Geographers 102, no. 1 (2012): 863-88o. doi:10.108o/0oo456o8.2011.6o2934.

Kinnunen, Tiina, and Ville Kivimäki, eds., Finland in World War II: History, Memory, Interpretations. Leiden: Brill, 2013.

Murre-van den Berg, Heleen. “'Our Jerusalem': Bertha Spafford Vester and Christianity

54 Swanström, From Failed Mission to Apocalyptic Admiration, 121.

55 Jalagin, "Transnationalising." 
in Palestine during the British Mandate." In Britain, Palestine and Empire: The Mandate Years, edited by Rory Miller, 67-83. Farnham, Surrey: Routledge, 2010.

Okkenhaug, Inger Marie. "Education, Culture and Civilization: Anglican Missionary Women in Palestine." In The Christian Communities of Jerusalem and the Holy Land: Studies in History, Religion and Politics, edited by A. O'Mahony, 171-199. Cardiff: University of Wales Press, 2003.

Okkenhaug, Inger Marie. "Children, Women and Welfare in Jerusalem." In A Swede in Jerusalem: Signe Ekblad and the Swedish School 1922-1948. En svenska i Jerusalem. Signe Ekblad och den svenska skolan 1922-1948, 87-101. Bethlehem: Diyar Publishing; Svenska Jerusalemföreningen/Swedish Jerusalem Society, 2012.

O'Mahony, Anthony. "The Christian Communities of Jerusalem and the Holy Land: A Historical and Political Survey." In The Christian communities of Jerusalem and the Holy Land: Studies in History, Religion and Politics, edited by A. O'Mahony, 1-37. Cardiff: University of Wales Press, 2012.

Renton, James. "Flawed Foundations: The Balfour Declaration and the Palestine Mandate." In Britain, Palestine and Empire: The Mandate Years, edited by Rory Miller, 15-37. Farnham, Surrey: Routledge, 2010.

Saarilahti, Toivo. Sata vuotta suomalaista lähetystyötä. 1, 3, Lähetystyön läpimurto: Suomen lähetysseuran toiminta kotimaassa 1895-1913. Helsinki: Suomen Lähetysseura, 1989 .

Sand, Shlomo. The Invention of the Land of Israel. From Holy Land to Homeland. Translated by Geremy Forman. London: Verso, 2013.

Shindler, Colin. A History of Modern Israel. 4th printing. Cambridge: Cambridge University Press, 2011.

Skjøtt, Bodil F. "Eli and Karen Bøgh—Bible Missionaries in Israel." Mishkan: A Forum on the Gospel and the Jewish People 41 (2004): 38-48. http://www.caspari.com/wp -content/uploads/2016/o6/mishkan41.pdf. Accessed June 12, 2018.

Småberg, Maria. Ambivalent Friendship: Anglican Conflict Handling and Education for Peace in Jerusalem 1920-1948. Lund: Lund University, 2005.

Swanström, André. From Failed Mission to Apocalyptic Admiration: Perspectives on Finnish Christian Sionism. Åbo: Åbo Akademi, 2007.

Wallendorff, Per. Suomen lähetysseuran juutalaislähetystyön historia. Suom. Aune Krohn. Helsinki: Suomen Lähetysseura, $195^{8}$. 